\title{
Highlight report: adaptations of the biliary tree to cholestasis
}

\author{
Reham Hassan ${ }^{1}$
}

Received: 23 May 2017 / Accepted: 29 May 2017 / Published online: 12 June 2017

(C) Springer-Verlag Berlin Heidelberg 2017

Recently, Peter Jansen and colleagues have published a comprehensive review article about the pathophysiology of cholestatic liver disease (Jansen et al. 2017). One of the central key messages of this article is that cholestatic liver disease typically evolves with anatomically an ascending course, where the early lesions occur 'downstream' in bile ducts, which later leads to 'upstream' bile salt mediated damage of hepatocytes. An interesting lesson learned from Jansen's article is that three topological domains of the biliary tree respond differently to cholestasis. Large bile ducts enlarge their diameter, which increases the capacity to conduct and accommodate biliary fluid (Strazzabosco 1997; Vartak et al. 2016). Upstream, the interlobular ducts undergo branching, and rejoining, which transforms a sparse mesh into a much denser mesh (Vartak et al. 2016). Moreover, the inner surface of the ducts becomes corrugated, which leads to a strong increase of the luminal duct surface and thereby increases bile resorption capacity. The bile canalicular network represents the most upstream domain of the biliary tract. In cholestasis, canaliculi show increased average diameters and an increase in the frequency of spine- or bleb-like protrusions into hepatocytes (Jansen et al. 2017). The causes of these changes are still controversially discussed and range from biochemically induced tight junctional remodeling and altered pericanalicular action to a possible consequence of increased canalicular pressure (Masyuk et al. 2001; Das et al. 2009; Liu et al. 2015).

Reham Hassan

Reham_Hassan@vet.svu.edu.eg

1 Forensic Medicine and Toxicology Department, Faculty of Veterinary Medicine, South Valley University, Qena, Egypt
Recently, research on cholestatic liver disease has been a particular focus in toxicological sciences (Miszczuk et al. 2015; Deharde et al. 2016; Reif et al. 2015; Barosso et al. 2016; Crespo Yanguas et al. 2016) and imaging and image analysis pipelines have been established to study morphological and functional changes in liver disease (Hammad et al. 2014; Ghallab et al. 2016; Hoehme et al. 2010; Drasdo et al. 2014; Godoy et al. 2013). Interestingly, drug induced liver injury (DILI) shows a different pathophysiology (Jansen et al. 2017). While autoimmune disorders, such as primary sclerosing cholangitis and primary biliary cholangitis first damage the biliary tree followed by damage of hepatocytes, the opposite order of key events is observed for most hepatotoxic chemicals, where damage to the parenchyme precedes compromised functions of the biliary tract. The review of Jansen and colleagues gives an excellent overview for those interested in how the functionality and stress responses of the biliary tract and hepatocytes are interlinked.

\section{References}

Barosso IR, Zucchetti AE, Miszczuk GS, Boaglio AC, Taborda DR, Roma MG, Crocenzi FA, Sánchez Pozzi EJ (2016) EGFR participates downstream of $\mathrm{ER} \alpha$ in estradiol-17 $\beta$-D-glucuronideinduced impairment of Abcc2 function in isolated rat hepatocyte couplets. Arch Toxicol 90(4):891-903. doi:10.1007/s00204-0151507-8 (Epub 2015 Mar 27)

Crespo Yanguas S, Willebrords J, Maes M, Da Silva TC, Veloso Alves Pereira I, Cogliati B, Zaidan Dagli ML, Vinken M (2016) Connexins and pannexins in liver damage. EXCLI J 15:177-186. doi:10.17179/excli2016-119 (eCollection 2016)

Das A, Yaqoob U, Mehta D, Shah VH (2009) FXR promotes endothelial cell motility through coordinated regulation of FAK and MMP-9. Arterioscler Thromb Vasc Biol 29(4):562-570. doi:10.1161/ATVBAHA.108.182725 (Epub 2009 Jan 15) 
Deharde D, Schneider C, Hiller T, Fischer N, Kegel V, Lübberstedt M, Freyer N, Hengstler JG, Andersson TB, Seehofer D, Pratschke J, Zeilinger K, Damm G (2016) Bile canaliculi formation and biliary transport in 3D sandwich-cultured hepatocytes in dependence of the extracellular matrix composition. Arch Toxicol 90(10):2497-2511. doi:10.1007/s00204-016-1758-z (Epub 2016 Jun 21)

Drasdo D, Hoehme S, Hengstler JG (2014) How predictive quantitative modelling of tissue organisation can inform liver disease pathogenesis. J Hepatol 61(4):951-956. doi:10.1016/j. jhep.2014.06.013 (Epub 2014 Jun 17)

Ghallab A, Cellière G, Henkel SG, Driesch D, Hoehme S, Hofmann U, Zellmer S, Godoy P, Sachinidis A, Blaszkewicz M, Reif R, Marchan R, Kuepfer L, Häussinger D, Drasdo D, Gebhardt R, Hengstler JG (2016) Model-guided identification of a therapeutic strategy to reduce hyperammonemia in liver diseases. J Hepatol 64(4):860-871. doi:10.1016/j.jhep.2015.11.018 (Epub 2015 Nov 27)

Godoy P, Hewitt NJ, Albrecht U, Woods CG, Xu JJ, Yarborough KM, Hengstler JG (2013) Recent advances in 2D and 3D in vitro systems using primary hepatocytes, alternative hepatocyte sources and non-parenchymal liver cells and their use in investigating mechanisms of hepatotoxicity, cell signaling and ADME. Arch Toxicol 87(8):1315-1530. doi:10.1007/s00204-013-1078-5 (Epub 2013 Aug 23. Review)

Hammad S, Hoehme S, Friebel A, von Recklinghausen I, Othman A, Begher-Tibbe B, Reif R, Godoy P, Johann T, Vartak A, Golka K, Bucur PO, Vibert E, Marchan R, Christ B, Dooley S, Meyer C, Ilkavets I, Dahmen U, Dirsch O, Böttger J, Gebhardt R, Drasdo D, Hengstler JG (2014) Protocols for staining of bile canalicular and sinusoidal networks of human, mouse and pig livers, threedimensional reconstruction and quantification of tissue microarchitecture by image processing and analysis. Arch Toxicol 88(5):1161-1183. doi:10.1007/s00204-014-1243-5 (Epub 2014 Apr 19)
Hoehme S, Brulport M, Bauer A, Bedawy E, Schormann W, Hermes M, Puppe V, Gebhardt R, Zellmer S, Schwarz M, Bockamp E, Timmel T, Hengstler JG, Drasdo D (2010) Prediction and validation of cell alignment along microvessels as order principle to restore tissue architecture in liver regeneration. Proc Natl Acad Sci USA 107(23):10371-10376. doi:10.1073/pnas.0909374107 (Epub 2010 May 19)

Jansen PL, Ghallab A, Vartak N, Reif R, Schaap FG, Hampe J, Hengstler JG (2017) The ascending pathophysiology of cholestatic liver disease. Hepatology 65(2):722-738. doi:10.1002/hep.28965

Liu X, Zhang X, Ji L, Gu J, Zhou M, Chen S (2015) Farnesoid X receptor associates with $\beta$-catenin and inhibits its activity in hepatocellular carcinoma. Oncotarget 6(6):4226-4238

Masyuk TV, Ritman EL, LaRusso NF (2001) Quantitative assessment of the rat intrahepatic biliary system by three-dimensional reconstruction. Am J Pathol 158(6):2079-2088

Miszczuk GS, Barosso IR, Zucchetti AE, Boaglio AC, Pellegrino JM, Sánchez Pozzi EJ, Roma MG, Crocenzi FA (2015) Sandwichcultured rat hepatocytes as an in vitro model to study canalicular transport alterations in cholestasis. Arch Toxicol 89(6):979-990. doi:10.1007/s00204-014-1283-x (Epub 2014 Jun 10)

Reif R, Karlsson J, Günther G, Beattie L, Wrangborg D, Hammad S, Begher-Tibbe B, Vartak A, Melega S, Kaye PM, Hengstler JG, Jirstrand M (2015) Bile canalicular dynamics in hepatocyte sandwich cultures. Arch Toxicol 89(10):1861-1870. doi:10.1007/ s00204-015-1575-9 (Epub 2015 Aug 18)

Strazzabosco M (1997) New insights into cholangiocyte physiology. J Hepatol 27(5):945-952

Vartak N, Damle-Vartak A, Richter B, Dirsch O, Dahmen U, Hammad S, Hengstler JG (2016) Cholestasis-induced adaptive remodeling of interlobular bile ducts. Hepatology 63(3):951-964. doi:10.1002/hep.28373 (Epub 2016 Jan 14) 